\title{
St. John's Ward as an Agent of Social Change in Toronto
}

AUTHOR: Olivia Lake

EDITED BY: Mary Peplinski, Julian Matheson, and Marisa Coulton

Traditional history has often dismissed or entirely omitted stories that are not affiliated with the lives of those belonging to the upper class. In more recent years, however, there has been a strong push for social historians to record the narratives of historically marginalized and forgotten communities. ${ }^{1}$ Among their efforts is an attempt to piece back together the history of Toronto's most notorious and impoverished 'slum' - The Ward. The Ward was originally known as Old Macaulaytown or St. John's Ward, but following an amalgamation of civic districts in 1891 the entire area bounded by Queen, Yonge, University and College Street simply became known as "The Ward." Deteriorating housing conditions, unsanitary buildings, and overcrowding were defining features of this neighborhood, garnering the attention of concerned city reformers. However, for ordinary Torontonians, more alarming than the deplorable living conditions was the cultural diversity among those who inhabited The Ward. From the 1880s to the twentieth century this neighborhood was the main arrival community for new immigrants to Ontario. ${ }^{3}$ These groups of people, who were visibly and culturally different than the White Anglo-Saxon majority, were perceived as a threat to the public health, social order and the morality of the rest of Toronto. The Ward thereby became an agent of social change in that it produced fears and anxieties amongst the general public about the changing landscape of their city. Consequently, press coverage on the neighborhood intensified, independent photographers sought to increase exposure of slum conditions, strategies of assimilation were introduced and eventually reforms were undertaken in this district of Toronto.
As The Ward's immigrant population exploded, the public increasingly stereotyped the community and its residents. Between 1871 and 1911, Toronto experienced massive population growth from 56,000 residents to over $376,000 .{ }^{4}$ The large-scale immigration of people from different countries to Toronto disturbed the traditional, homogenous composition of the city, with foreignborn residents accounting for 10 percent of the population at the end of $1911 . .^{5}$ These immigrants were predominantly unmarried Jews, Italians, and Chinese men who were seeking refuge in a new country following the end of the First World War. The public saw the arrival of these new groups as an invasion of 'Toronto the Good,' a phrase commonly used to describe the city's native white population and their commitment to Christian values. ${ }^{6}$ Immigrants to The Ward openly participated in religious practices and ethnic traditions which respectable Torontonians condemned as morally inferior to their own ways of life. ${ }^{7}$ Antisemitism was common in areas heavily populated with Jewish immigrants and synagogues. ${ }^{8}$ Disapproving public attitudes towards The Ward were also documented in the news coverage of the time. For example, in 1909, one alarmed journalist at the Globe and Mail published an expose on the appearance of the Toronto slum so that members of the public would be able to safely avoid it. ${ }^{9}$ Moreover, after several reports were released detailing robberies in the area, The Ward's residents gained a reputation as criminal and deviant. ${ }^{10}$ The unkempt appearance of these individuals due to their substandard living quarters helped further solidify this image in the minds of the public. In 1911, a biology professor from the University of Toronto, Ramsay Wright, described the district as "a cancer of the modern 
civic organism."11 Many people agreed with Wright's assertion and felt that The Ward was a corruptive agent in the city, responsible for the spread of poverty, disease, and nefarious activity. However, criticisms of the Ward were in many ways misguided and reductionist. Although the Ward's residents did appear noticeably unclean compared to the rest of Toronto's citizens and petty crimes did occur, these people were not inherently deviant. In their attempts at defining The Ward, Canadians failed to address the systemic causes that lead to the disenfranchisement of this community and instead focused only on visible differences. The prevailing opinion of St. John's Ward was, therefore, one that reflected the general anxieties of Toronto's native population, but it did not represent the actual conditions of the neighborhood.

When prominent community leaders began to publicize information they had gathered on The Ward, these public feelings of concern and frustration intensified. For example, in his books My Neighbor and Strangers at Our Gates, famous author J.S. Woodsworth painted a grim picture of the moral and physical degradation in Canada's big cities due to increased immigration. ${ }^{12}$ These detailed descriptions caused panic among many Canadians. In Toronto, the most influential person in the spread of awareness about slum conditions was Charles Hastings, the city's medical health officer. ${ }^{13}$ In 1911, Hastings performed a report on The Ward which revealed that most houses lacked plumbing and were only heated by a kitchen stove. A total of thirty-five residents lacked fresh water supply entirely. In addition to these structural flaws, The Ward was crawling with disease due to overcrowding and limited access to sanitary amenities. A survey in 1913, found there were as many as twenty-seven men living in only six rooms at 72 Terauley Street. ${ }^{14}$ Hastings warned the public that the contamination of one area would inevitably spread to the remaining parts of the city because, "disease did not respect social standing." 15 This quote indicates that Hastings wanted to expose the circumstances under which The Ward's residents were living because he was concerned about how this would affect the rest of the city. Taking an innovative approach to advocacy and wanting decision makers to see these conditions with their own eyes, Hastings hired Arthur Scott Goss to photograph The Ward.

As a committed social documentary photographer, Arthur Goss helped configure the image of Toronto's Lower Ward as an area in need of immense gentrification. Unlike other popular photojournalists of the time who attempted to capture an objective view of their subjects, Goss strived to depict social realities that would elicit an emotional response from Toronto's middle- and upper-classes. The photographs that he produced for Hastings's report effectively captured the plight of immigrant families living in The Ward. These photographs, as well as those taken by his predecessor William James, show in extreme detail the immense hardships faced by The Ward's residents. The photographs depict the neighborhood's distinctive rundown wooden cottages, children in ragged clothes, dangerous working environments at Eaton's and Simpson's, overflowing sewage, and other challenges of everyday life the residents of the neighborhood had to handle. Hasting and Goss' determined efforts at exposing these appalling environments is again a reflection of their personal fears for the future welfare of the entire city. Unfortunately, Hastings and Goss' work also helped perpetuate negative and dishonest stereotypes about The Ward. Throughout the 1910s, news reporters reacted to Goss's searing images with distress. Using terms like 'vagrant' and 'feeble-minded,' reporters blamed immigrants for bringing these problems to their city. ${ }^{16}$ Nevertheless, after this information was made available to the public, very few people were able to ignore the injustices this community was suffering. The Ward was propelled to the forefront of a national conversation regarding the need for reform in Canada's cities. ${ }^{17}$

Medical reforms in The Ward materialized in a number of different ways. Among the most controversial of these reforms was the Harrison 
Baths, opened on November 1st, 1909 on 3 Stephanie Street, just a few blocks west of The Ward. ${ }^{18}$ In Hastings' medical report, he recorded that of 1,653 homes in The Ward, only 160 had indoor plumbing, meaning that most residents had no way to clean themselves. ${ }^{19}$ At the Harrison Baths, however, users could access showers and baths for five cents, and for ten cents, they could use the diving pool, where swimming lessons were also offered. ${ }^{20}$ Consequently, in the first week of operation over 2000 people utilized the facility. ${ }^{21}$ Other medical reforms included the establishment of public health nurses, the pasteurization of milk, and regulations on privies and water supplies. ${ }^{22}$ These initiatives helped reduce malnutrition and the spread of infection in The Ward. Additionally, the reforms also represented the way the Toronto public's attitudes towards the community had evolved. Though most people continued to speak of The Ward with contempt, there was greater support for trying to alleviate the suffering of the neighborhood's residents.

Unfortunately, most attempts at improving the disastrous housing conditions in The Ward were ineffective. In 1912, The Public Health Act placed restrictions on the number of tenements permitted in a single home. ${ }^{23}$ However, these regulations were difficult to control, and, as a result, the substandard quality of residences in The Ward did not improve. In that same year, The Toronto Housing Company was formed in order to construct small houses that would be rented inexpensively to low-income families. ${ }^{24}$ The 242 cottages built failed to satisfy Toronto's booming population and consequently, hazardous overcrowding within these dwellings persisted. ${ }^{25}$ For the period that The Ward existed, the Toronto municipal government was simply not yet equipped with the tools and resources required to eradicate poverty of this magnitude. The continuing efforts of the city council, however, indicate that people were unsettled by these issues and wanted their representatives to continue to work towards improving living conditions in The Ward.
Beginning in the 1880s, attempts to purify The Ward's suspected immoral activities were led by clergymen, temperance societies and women's organizations. ${ }^{26}$ In Tomorrow's Metropolis, Paul Rutherford wrote that this sort of reform was, "an experiment in social engineering, an attempt to force the city dweller to conform to the public mores of the church-going middle class." ${ }^{27}$ For example, protestant missionaries frequently visited the slum district looking to gain converts by enticing young Jewish children with candy and toys around Christmas time. ${ }^{28}$ In Dr. Stephen Speisman's book, The Jews in Toronto, he identifies the Hester How School and the Elizabeth Street Playground as popular locations for attempted evangelizations. ${ }^{29}$ While these missionary efforts were extremely distressing for Jewish Rabbis in the community, most were unsuccessful. Additionally, on Sundays policemen patrolled the streets of The Ward according to the Lord's Day Act. ${ }^{30}$ This Act prohibited retail sales and the use of public transportation on Sundays, however, more significantly, it allowed municipal authorities to enforce a compulsory Protestant Sunday. ${ }^{31}$ Furthermore, though policing actions on Sundays were reduced after the Second World War, the overturning of this law did not take place until 1982 when the Charter of Rights was established. ${ }^{32}$ This means that for decades, religious minorities in The Ward were forcibly subject to the culturally-specific Christian moral codes of 'Toronto the Good.'

Child welfare programs in The Ward were often prioritized, as reformers recognized that second-generation immigrants were more easily assimilated into Canadian culture than firstgeneration immigrants. Believing that the child was Toronto's best hope for the future, reformers like J.J. Kelso, a former reporter and founder of The Children's Aid Society, advocated for a special children's charter, parks and recreational centers and new schools that would accommodate the schedules of students working part-time to support their families. ${ }^{33}$ In September of 1911, Kelso established Toronto's second settlement building in The Ward, the Central Neighborhood 
House $(\mathrm{CNH}){ }^{34}$ Located at 84 Gerrard Street, $\mathrm{CNH}$ offered programs for immigrants to learn the English language as well as other programs that would help them become 'good Canadians.' The $\mathrm{CNH}$ was headed by Elizabeth Neufeld, who in 1914 also led a march of over 200 children to City Hall where they petitioned council for $\$ 20,000$ for recreational equipment. ${ }^{35}$ Neufeld's march as well as mounting pressures from groups like the Toronto Playground Association, inspired the government to fund eight new parks in the city that year. At the Elizabeth Street Playground in The Ward children enjoyed swings, teeter-totters, climbing structures, basketball hoops, and baseball diamonds. ${ }^{36}$ Social reformers were enthusiastic about this progress because they believed supervised play would help transform The Ward's immigrant children into sociable and enlightened citizens. ${ }^{37}$ As a result, while these playgrounds helped promote a healthy and active lifestyle, they also facilitated the conformity reformers hoped to achieve within the community.

The overwhelming rhetoric in nineteenth century Toronto largely portrayed The Ward as a place of destitution and vice. For the members of this community, however, The Ward represented something entirely different. In 1964, when the construction of the new City Hall had been finalized, a journalist from the Toronto Star wrote an obituary to the neighborhood titled, "The Ward of the 1900 was a harsh ghetto, but to thousands it symbolized freedom." 38 Located near to the immigrant arrival points at Union Station and the Great Western Station, The Ward became a home to people from all over the world. ${ }^{39}$ The majority of these people came to Canada to escape violence and persecution elsewhere. That being the case of most immigrants who found themselves living in The Ward, the neighborhood was not only a place of occupancy, but also an area of refuge and opportunity. In the 1840s, for example, St. John's Ward became a popular destination for African Americans fleeing slavery in the United States..$^{40}$ In addition to offering cheap housing and employment opportunities, The Ward extended community acceptance to these refugees. ${ }^{41}$ In The Ward, like the rest of Toronto's residential districts, there was no segregation. Blacks and Whites could attend the same churches and schools and were deemed equal under Canadian law. Among The Ward's residents would be William Peyton Hubbard, who later became Toronto's first black deputy mayor. ${ }^{42}$ Abolitionist organizations were also common in The Ward, helping to protect Black immigrants from the Fugitive Slave Act passed in $1850 .{ }^{43}$ As the African American population grew, The Ward steadily gained another reputation - a vibrant community where Black people could exercise freedom and their right to self-determination. ${ }^{44}$ The Jewish population also found sanctuary in The Ward as many of them were able to flee the violent pogroms taking place at the time in Eastern Europe. ${ }^{45}$ Therefore, while reformers discussed The Ward as a social problem in need of treatment or removal, the immigrant community responded to this neighborhood with gratitude and optimism because, for many of them, it offered a second chance at life.

The continued existence of The Ward forced social change in Toronto because the Toronto public, namely the middle- and upperclasses, feared that the neighborhood's foreignborn population would spread deadly diseases, encourage immoral activity and corrupt the religious hegemony of what had previously been a predominantly white Protestant community. St. John's Ward, however, is also significant in the way it helped new immigrants safely acclimatize to life in Canada. By concentrating in one area of the city, these various ethnic communities were able to build support networks, establish financial secureness and then eventually integrate into the greater society. Furthermore, the Ward's first generation of residents pioneered the way for the establishment of other micro-communities in Toronto that are recognized and celebrated on the world stage. Neighborhoods including Little Italy, Koreatown, Greek Town, the Gay Village and Kensington Market were established because of the diversity that was first cultivated by immigrants living in The 
Ward. The diversity, acceptance and toleration which are signature characteristics of Today's Toronto have roots in The Ward, along with the resilient individuals who called this neighborhood their home.

\section{ENDNOTES:}

1. John Lorinc, Michael McClelland, Ellen Scheinberg and Tatum Taylor, The Ward: the life and loss of Toronto's first immigrant neighborhood. (Coach House, 2015) 290.

2. Alain F.J Artibise and Gilbert A. Stelter, The Usable Urban Past: Planning and Politics in the Modern Canadian City. (Toronto: Macmillian Company of Canada Limited, 1979) 43.

3. Ibid., 43.

4. John Lorinc, Michael McClelland, Ellen Scheinberg and Tatum Taylor, The Ward: the life and loss of Toronto's first immigrant neighborhood. (Coach House, 2015) 14.

5. John Lorinc, Michael McClelland, Ellen Scheinberg and Tatum Taylor, The Ward: the life and loss of Toronto's first immigrant neighborhood. (Coach House, 2015) 15.

6. Ibid., 15.

7. W.E. Mann, The Underside of Toronto. (Toronto: McClelland and Stewart, 1972) 34.

8. Richard Dennis, "Property and Propriety: Jewish Landlords in Early Twentieth-Century Toronto." Transactions of the Institute of British Geographers 22, no. 3 (1997): 380. http://www.jstor. org.proxy1.lib.uwo.ca/stable/623224.

9. John Lorinc, Michael McClelland, Ellen Scheinberg and Tatum Taylor, The Ward: the life and loss of Toronto's first immigrant neighborhood. (Coach House, 2015) 291.

10. Alain F.J Artibise and Gilbert A. Stelter, The Usable Urban Past: Planning and Politics in the Modern Canadian City. (Toronto: Macmillian Company of Canada Limited, 1979) 46.

11. Allan Levine, Toronto: A Biography of a City (British Columbia: Douglas \& McIntyre, 2013), 211. 12. Paul Rutherford, "Tomorrow's Metropolis: The Urban Reform Movement in Canada, 18801920," Canadian Historical Association. Historical Papers 6, no. 1 (1971): 204. doi:10.7202/030466ar. 13. Richard Dennis. "Property and Propriety: Jewish Landlords in Early Twentieth-Century
Toronto." Transactions of the Institute of British Geographers 22, no. 3 (1997): 380. http://www.jstor. org.proxy1.lib.uwo.ca/stable/623224.

14. Alain F.J Artibise and Gilbert A. Stelter, The Usable Urban Past: Planning and Politics in the Modern Canadian City. (Toronto: Macmillian Company of Canada Limited, 1979) 45.

15. Paul Rutherford, "Tomorrow's Metropolis: The Urban Reform Movement in Canada, 1880-1920," 205. doi:10.7202/030466ar.

16. John Lorinc, Michael McClelland, Ellen Scheinberg and Tatum Taylor, The Ward: the life and loss of Toronto's first immigrant neighborhood. (Coach House, 2015) 114.

17. Ibid, 114.

18. Ibid, 254.

19. Alain F.J Artibise and Gilbert A. Stelter, The Usable Urban Past: Planning and Politics in the Modern Canadian City. (Toronto: Macmillian Company of Canada Limited, 1979) 44.

20. Ibid, 254.

21. John Lorinc, Michael McClelland, Ellen Scheinberg and Tatum Taylor, The Ward: the life and loss of Toronto's first immigrant neighborhood. (Coach House, 2015) 254.

22. Ibid., 226.

23. Alain F.J Artibise and Gilbert A. Stelter, The Usable Urban Past: Planning and Politics in the Modern Canadian City. (Toronto: Macmillian Company of Canada Limited, 1979) 247.

24. Ruben C. Bellan Canada's Cities: A History. (Winnipeg: The Whitefield Press, 2003) 168-169. 25. Ibid., 168.

26. Paul Rutherford, "Tomorrow's Metropolis: The Urban Reform Movement in Canada, 1880-1920," 205. doi:10.7202/030466ar.

27. Paul Rutherford, "Tomorrow's Metropolis: The Urban Reform Movement in Canada, 1880-1920," 205. doi:10.7202/030466ar.

28. Alain F.J Artibise and Gilbert A. Stelter, The Usable Urban Past: Planning and Politics in the Modern Canadian City. (Toronto: Macmillian Company of Canada Limited, 1979) 47.

29. John Lorinc, Michael McClelland, Ellen Scheinberg and Tatum Taylor, The Ward: the life and loss of Toronto's first immigrant neighborhood. (Coach House, 2015) 75.

30. Ibid., 71. 
31. John Lorinc, Michael McClelland, Ellen Scheinberg and Tatum Taylor, The Ward: the life and loss of Toronto's first immigrant neighborhood. (Coach House, 2015) 75.

32. Ibid., 75.

33. Alain F.J Artibise and Gilbert A. Stelter, The Usable Urban Past: Planning and Politics in the Modern Canadian City. (Toronto: Macmillian Company of Canada Limited, 1979) 45.

34. Ibid., 66.

35. John Lorinc, Michael McClelland, Ellen

Scheinberg and Tatum Taylor, The Ward: the life and loss of Toronto's first immigrant neighborhood. (Coach House, 2015) 186.

36. Ibid.,186.

37. Kai Wood Mah, "Children, Medicine, and the Built Environment of Early Twentieth-Century Toronto," Children, Youth and Environments 25, no. 3 (2015): 100. doi:10.7721/chilyoutenvi.25.3.0090. 38. John Lorinc, The Ward: the life and loss of Toronto's first immigrant neighborhood. (Coach House, 2015), 290.

39. Melanie Kwong, "The Ward." Heritage Toronto, accessed November 25, 2018, http://heritagetoronto. org/the-ward/.

40. Lorinc, John. "The Black Community in St. John's Ward." The City of Toronto, accessed March 2, 2018, https://www.toronto.ca/explore-enjoy/ history-art-culture/black-history-month/the-blackcommunity-in-st-johns-ward/.

41. Melanie Kwong, "The Ward." Heritage Toronto, accessed November 25, 2018, http://heritagetoronto. org/the-ward/.

42. John Lorinc, The Ward: the life and loss of Toronto's first immigrant neighborhood. (Coach House, 2015), 67.

43. Ibid., 68.

44. Lorinc, John. "The Black Community in St. John's Ward." The City of Toronto, accessed March 2, 2018, https://www.toronto.ca/explore-enjoy/ history-art-culture/black-history-month/the-blackcommunity-in-st-johns-ward/.

45. Dennis, Richard. "Property and Propriety: Jewish Landlords in Early Twentieth-Century Toronto." Transactions of the Institute of British Geographers 22, no. 3 (1997): 377-397. http:// www.jstor.org.proxy1.lib.uwo.ca/stable/623224.
BIBLIOGRAPHY:

Artibise, Alain F.J and Gilbert A. Stelter. The Usable Urban Past: Planning and Politics in the Modern Canadian City. Toronto: Macmillian Company of Canada Limited, 1979.

Bellan, Ruben C. Canada's Cities: A History. Winnipeg: The Whitefield Press, 2003.

Dennis, Richard. "Property and Propriety: Jewish Landlords in Early Twentieth-Century Toronto." Transactions of the Institute of British Geographers 22, no. 3 (1997): 377-97. http://www.jstor.org.proxy1.lib.uwo. ca/stable/623224.

G. Warecki. Draft Chapter Two, Biography of J.R Dymond. January 2018.

Kai Wood Mah. "Children, Medicine, and the Built Environment of Early TwentiethCentury Toronto." Children, Youth and Environments 25, no. 3 (2015): 90-108. doi:10.7721/chilyoutenvi.25.3.0090.

Kwong, Melanie. "The Ward." Heritage Toronto, accessed November 25, 2018, http:// heritagetoronto.org/the-ward/.

Levine, Allan. Toronto, A Biography of a City. British Columbia: Douglas \& Mclntyre, 2013.

Lorinc, John, "The Black Community in St. John's Ward." The City of Toronto, accessed March 2, 2018, https://www.toronto.ca/exploreenjoy/history-art-culture/black-history-month/ the-black-community-in-st-johns-ward/.

Lorinc, John, Michael McClelland, Ellen Scheinberg and Tatum Taylor. The Ward: the life and loss of Toronto's first immigrant neighborhood. Coach House, 2015.

Mann, W.E. The Underside of Toronto. Toronto: McClelland and Stewart, 1972, 11-17, 33-74.

Rutherford, Paul. "Tomorrow's Metropolis: The Urban Reform Movement in Canada, 18801920". Canadian Historical Association. Historical Papers 6, no. 1 (1971): 203-224. doi:10.7202/030466ar 